\title{
Highly Enantioselective Darzens Reaction of a Camphor-Derived Sulfonium Amide to Give Glycidic Amides and their Applications in Synthesis
}

\author{
Varinder K. Aggarwal*, George Hynd, Willy Picoul, Jean-Luc Vasse.
}

\section{Supporting Information}

\section{General methods.}

Flash chromatography was performed on silica gel (Merck Kiesegel $60 \mathrm{~F}_{254}$ 230-400 mesh). TLC was performed on aluminium backed silica plates $\left(60 \mathrm{~F}_{254}\right)$ which were developed using standard visualizing agents: UV fluorescence (254 and $366 \mathrm{~nm}$ ), molybdic acid / $\Delta$, anisaldehyde / $\Delta$, permanganate $/ \Delta$. Melting points were determined on a Khöfler hot stage. Infrared spectra were recorded on a Perkin-Elmer Spectrum One FT-IR spectrometer. Only selected absorbencies $\left(v_{\max }\right)$ are reported. ${ }^{1} \mathrm{H}$ NMR spectra were recorded at 250,270 or $400 \mathrm{MHz}$ on Bruker AC-250, Delta GX/270 or Delta GX/400 instruments, respectively. Chemical shifts $\left(\delta_{\mathrm{H}}\right)$ are quoted in parts per million $(\mathrm{ppm})$, referenced to TMS. ${ }^{13} \mathrm{C}$ NMR spectra were recorded at either 68 or $100 \mathrm{MHz}$ on Delta GX/270 or Delta $\mathrm{GX} / 400$ instruments, respectively. Chemical shifts $\left(\delta_{\mathrm{C}}\right)$ are quoted in parts per million $(\mathrm{ppm})$, referenced to the appropriate residual solvent. Degenerate peaks are prefixed by the number of carbons. Low resolution mass spectra $(\mathrm{m} / \mathrm{z})$ were recorded on a Micromass Analytical Autospec spectrometer with only molecular ions $\left(\mathrm{M}^{+}\right)$, and major peaks being reported with intensities quoted as percentages of the base peak. High-resolution mass spectra were recorded on a Micromass Analytical Autospec spectrometer. Microanalyses were performed using a Carlo Erba EA1108. Ee values were determined by chiral HPLC on a Chiralcel OD, ODH or OJ column. All chemicals were purchased from Aldrich, Fluka or Lancaster, and used as delivered. Solvents are purified by passing through a solvent column prior to use.

(-)-(1R, 2S)-2-Methoxy-exo-3-(methylthio)-1,7,7-trimethylbicyclo[2.2.1]-heptane (1).

This compound was prepared according to the literature. ${ }^{1}$ However, the precursor $(1 R, 3 R)-3$ (Methylthio)-1,7,7-trimethylbicyclo[2.2.1]-heptan-2-one was prepared using DMPU (3 eq) instead of HMPA (3 eq), and obtained as a colorless oil in $88 \%$ yield. $[\alpha]_{\mathrm{D}}+93.0\left(c\right.$ 2.0, acetone) $\left[\right.$ lit., $[\alpha]_{\mathrm{D}}+93.3$ (c 2.0, acetone)].

(Diethylcarbamoyl)methyl-[(1R, $\quad 2 S, \quad 3 R)$-2-methoxy-1,7,7-trimethylbicyclo[2.2.1] hept-3yl]methylsulfonium bromide (2).

A 10/1 mixture of diastereomeric sulfonium salt was prepared by quantitative alkylation of sulfide $\mathbf{1}$ (1 eq) with $N, N$-diethyl-bromoacetamide ( $1 \mathrm{eq}$ ) in a small amount of acetone for 24 hours. The crude solid obtained was washed with hexane, filtrated, then recrystallised in hexane/acetone to give diastereopure 2 as a white crystal. mp $105-106{ }^{\circ} \mathrm{C},[\alpha]_{\mathrm{D}}+111.2$ (c 0.17 , dichloromethane); IR (film) 3055,1422 , $1266,896,738,704 \mathrm{~cm}^{-1} ; \delta_{\mathrm{H}}\left(250 \mathrm{MHz}, \mathrm{CDCl}_{3}\right) 6.52\left(\mathrm{~d}, J_{\mathrm{AB}} 15.9,1 \mathrm{H}\right), 5.50(\mathrm{~d}, J 7.6,1 \mathrm{H}), 4.12(\mathrm{~d}$, $\left.J_{\mathrm{AB}} 15.9,1 \mathrm{H}\right), 3.76(\mathrm{~d}, J 7.6,1 \mathrm{H}), 3.65(\mathrm{~m} ., 1 \mathrm{H}), 3.53(\mathrm{~s}, 3 \mathrm{H}), 3.51(\mathrm{~m} ., 1 \mathrm{H}), 3.34(\mathrm{~m} ., 2 \mathrm{H}), 3.23(\mathrm{~s}$, $3 \mathrm{H}), 2.02(\mathrm{~d}, J 4.3,1 \mathrm{H}), 2.00-1.80(\mathrm{~m}, 1 \mathrm{H}), 1.60-1.10(\mathrm{~m}, 3 \mathrm{H}), 1.28(\mathrm{t}, J 7.3,3 \mathrm{H}), 1.17(\mathrm{t}, J 7.3,3 \mathrm{H})$, $1.17(\mathrm{~s}, 3 \mathrm{H}), 1.06(\mathrm{~s}, 3 \mathrm{H}), 0.87(\mathrm{~s}, 3 \mathrm{H}) ; \delta_{\mathrm{C}}\left(63 \mathrm{MHz}, \mathrm{CDCl}_{3}\right)$ 162.2, 88.4, 61.4, 59.6, 51.4, 48.0, 47.7, 47.4, 43.0, 41.0, 32.1, 27.4, 23.2, 21.0, 20.5, 14.3, 12.3, 11.7; MS (EI) m/z. 281 (84), 167 (50), 115 (100), 100 (62), 86 (51), 72 (60), 58 (64); MS (CI) m/z, 328 (76), 194 (62), 135 (72), 116 (100); Anal. calcd for $\mathrm{C}_{18} \mathrm{H}_{34} \mathrm{NO}_{2} \mathrm{BrS}$ : C, 52.93; H, 8.39; N, 3.43. Found: C, 52.86; H, 8.41; N, 3.39; HRMS calcd for $\mathrm{C}_{18} \mathrm{H}_{34} \mathrm{NO}_{2} \mathrm{~S}^{+}$328.2310, found 328.2311.

General procedure for epoxidation of aromatic aldehydes $3 \mathrm{a}^{2}{ }^{2} 3 \mathrm{~b}-3 \mathrm{~h} .^{3}$

To a solution of aldehyde $(0.2 \mathrm{mmol})$ and chiral sulfonium salt $2(0.25 \mathrm{mmol})$ in ethanol $(0.9 \mathrm{~mL})$ at $50{ }^{\circ} \mathrm{C}$ was added powdered potassium hydroxide $(0.5 \mathrm{mmol})$. The reaction mixture was stirred at this temperature for 48 hours. After removal of the solvent under reduced pressure, the crude mixture was directly purified by flash chromatography on silica gel to give the pure epoxide.

\footnotetext{
${ }^{1}$ Li, A. H.; Dai, L. X.; Hou, X. L.; Huang, Y. Z.; Li, F. W. J. Org. Chem. 1996, 61, 489. Sulfide 1 was prepared according to the litterature. However, the precursor $(1 R, 3 R)$-3-(Methylthio)-1,7,7-trimethylbicyclo[2.2.1]-heptan2 -one was prepared using DMPU (3 eq) instead of HMPA (3 eq), and obtained as a colorless oil in $88 \%$ yield. $[\alpha]_{\mathrm{D}}$ $+93.0^{\circ}(c 2.0$, acetone $)\left[\right.$ lit. $[\alpha]_{\mathrm{D}}+93.3^{\circ}(c 2.0$, acetone $\left.)\right]$.

${ }^{2}$ Meth-Cohn, O.; Horak, R. M.; Fouche, G. J. Chem. Soc, Perkin Trans. I 1994, 1517.

${ }^{3}$ Zhou, Y.-G.; Hou, X.-L.; Dai, L.-X.; Xia, L.-J.; Tang, M.-H. J. Chem. Soc, Perkin Trans. I 1999, 77.
} 
General procedure for epoxidation of aliphatic aldehydes $3 \mathrm{i},{ }^{3} 3 \mathrm{j}$ and $3 \mathrm{k}$.

To a solution of aldehyde $(0.5 \mathrm{mmol})$ and chiral sulfonium salt $2(0.25 \mathrm{mmol})$ in ethanol $(0.9 \mathrm{~mL})$ at $50{ }^{\circ} \mathrm{C}$ was added powdered potassium hydroxide $(0.5 \mathrm{mmol})$. The reaction mixture was stirred at this temperature for 72 hours. After removal of the solvent under reduced pressure, the crude mixture was directly purified by flash chromatography on silica gel to give the pure epoxide.

trans-N,N-Diethyl-3-iso-propyl-2,3-epoxypropionamide (3j).

This compound was obtained according to the general procedure after purification by flash chromatography on silica gel with a mixture of light petroleum ether and ethyl acetate (4/1) as the eluant to give a colourless oil in $79 \%$ yield and $10 \%$ ee, $[\alpha]_{\mathrm{D}}+7.5$ (c 1.6, chloroform); IR (film) 2970 , $2935,2875,1645,1465,1420,1380,1365,1265,900,815 \mathrm{~cm}^{-1} ; \delta_{\mathrm{H}}\left(400 \mathrm{MHz}, \mathrm{CDCl}_{3}\right) 1.02(\mathrm{~d}, J 6.8$, $3 \mathrm{H}), 1.06(\mathrm{~d}, J 6.8,3 \mathrm{H}), 1.14(\mathrm{t}, J 7.1,3 \mathrm{H}), 1.26(\mathrm{t}, J 7.1,3 \mathrm{H}), 1.66(\mathrm{~m}, 1 \mathrm{H}), 2.95(\mathrm{dd}, J 6.8,2.2,1 \mathrm{H})$, 3.31-3.54 (m, 5H), 3.44; $\delta_{\mathrm{C}}\left(100 \mathrm{MHz}, \mathrm{CDCl}_{3}\right) 12.9,14.8,18.3,18.9,30.2,40.7,41.4,52.6,63.1$, 166.8; Chiracel OJ, hexane-i-PrOH (99:1) $0.7 \mathrm{~mL} / \mathrm{min}, 21.7 \mathrm{~min}$ (major), $23.6 \mathrm{~min}$ (minor).

trans- $N, N$-Diethyl-3-tert-butyl-2,3-epoxypropionamide (3k).

This compound was obtained according to the general procedure after purification by flash chromatography on silica gel with a mixture of light petroleum ether and ethyl acetate (3/1) as the eluant to give a colourless oil in $84 \%$ yield and $93 \%$ ee. $[\alpha]_{\mathrm{D}}-36.6$ ( $c 0.76$, chloroform); IR (film) $2960,2872,1648,1380,1364 \mathrm{~cm}^{-1} ; \delta_{\mathrm{H}}\left(400 \mathrm{MHz} \mathrm{CDCl}_{3}\right) 0.98(\mathrm{~s}, 9 \mathrm{H}), 1.14(\mathrm{t}, J 7.3,3 \mathrm{H}), 1.25(\mathrm{t}, J$ $7.0,3 \mathrm{H}), 2.94(\mathrm{~d}, J 2.2,1 \mathrm{H}), 3.31-3.54(\mathrm{~m}, 4 \mathrm{H}), 3.44(\mathrm{~d}, J 2.2,1 \mathrm{H}) ; \delta_{\mathrm{C}}\left(100 \mathrm{MHz}, \mathrm{CDCl}_{3}\right) 12.9,14.8$, 25.7, 30.8, 40.6, 41.3, 50.8, 65.6, 167.0; MS (CI) m/z $200\left(\mathrm{M}+\mathrm{H}^{+}, 7\right), 182$ (28), 142 (10), 130 (38), 59 (100); HRMS (EI) calcd for $\mathrm{C}_{11} \mathrm{H}_{21} \mathrm{NO}_{2}$ 199.1572, found 199.1578; Chiracel OJ, hexane-i-PrOH (99 : 1) $0.7 \mathrm{~mL} / \mathrm{min}, 17.2 \mathrm{~min}(2 S, 3 R), 18.6 \mathrm{~min}(2 R, 3 S)$.

General procedure for addition of organolithium reagents to epoxyamides.

To a solution of epoxyamide $(0.25 \mathrm{mmol})$ in $\mathrm{THF}(0.75 \mathrm{~mL})$ at $-78{ }^{\circ} \mathrm{C}$ was treated dropwise with appropriate organolithium reagents (1.5 equivalent). The reaction mixture was stirred at this temperature for 30 minutes. Water $(0.5 \mathrm{~mL})$ and ether were added $(0.5 \mathrm{~mL})$. The organic layer was separated and the aqueous layer re-extracted with ether $(3 \mathrm{x} 2 \mathrm{~mL})$. The combined organic layers were dried over $\mathrm{MgSO}_{4}$, concentrated, and the residue purified by flash chromatography with a mixture of light petroleum ether and ethyl acetate (12/1 to 8/1) as the eluant to give the pure epoxyketone.

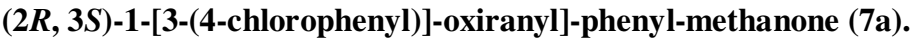

This compound was obtained according to the general procedure using a solution of phenyllithium ( $2 \mathrm{M}$ solution in cyclohexane/ether 70/30, $190 \mu \mathrm{mol}$ ) after flash chromatography with a mixture of light petroleum ether and ethyl acetate $(9 / 1)$ as the eluant to give a white solid in $88 \%$ yield and $98 \%$ ee. $\mathrm{mp}$ 77-78 ${ }^{\circ} \mathrm{C}$, [lit. $\left.{ }^{4}, \mathrm{mp} 78-80{ }^{\circ} \mathrm{C}\right],[\alpha]_{\mathrm{D}}-208$ (c 1.1, dichloromethane), [lit. ${ }^{4},[\alpha]_{\mathrm{D}}-207.8$ (c 1.17 dichloromethane), 98\% ee]; IR (film) 1690, 1595, 1580, 1495, 1450, 1395, 1230, 1085, 820, 805, 700, $685 \mathrm{~cm}^{-1} ; \delta_{\mathrm{H}}\left(400 \mathrm{MHz}, \mathrm{CDCl}_{3}\right) 4.06(\mathrm{~d}, J 2.0,1 \mathrm{H}), 4.25(\mathrm{~d}, J 2.0,1 \mathrm{H}), 7.28-7.68(\mathrm{~m}, 7 \mathrm{H}), 7.35(\mathrm{dd}, J$ 8.3, 1.3 2H), $\delta_{\mathrm{C}}\left(100 \mathrm{MHz}, \mathrm{CDCl}_{3}\right)$ 58.7(1), 61.0, 127.2, 128.7, 129.10, 129.15, 134,1, 135.0, 135.5, 192.8; MS (EI) m/z $258\left(\mathrm{M}^{+}, 25\right), 139$ (32),125 (29), 105 (100), 89 (33), 77 (69); HRMS calcd for $\mathrm{C}_{10} \mathrm{H}_{9} \mathrm{ClO}_{2}^{+}$196.0291, found 196.0282

(2R, 3S)-1-[3-(4-chlorophenyl)]-oxiranyl]-ethanone (7b).

This compound was obtained according to the general procedure using a solution of methyllithium (1.6M, in diethylether, $235 \mu \mathrm{L})$ after purification by flash chromatography on silica gel with a mixture of light petroleum ether and ethyl acetate (5/1) as the eluant to give a white solid in $81 \%$ yield and $99 \%$ ee. $\mathrm{mp} 62^{\circ} \mathrm{C}$; $[\alpha]_{\mathrm{D}}-102$ (c 1, chloroform); IR (film) $1700,1490,1360,1255,1090,880,820 \mathrm{~cm}^{-1} ; \delta_{\mathrm{H}}$ $\left(400 \mathrm{MHz}, \mathrm{CDCl}_{3}\right) 2.19$ (s, 3H), $3.45(\mathrm{~d}, J 1.5,1 \mathrm{H}), 3.99$ (d, J 1.5, 1H), 7.22 (d, J 8.3, 2H), 7.35 (d, $J$ $8.3,2 \mathrm{H}) ; \delta_{\mathrm{C}}\left(100 \mathrm{MHz}, \mathrm{CDCl}_{3}\right) 24.8,57.1,63.4,127.1,129.0,133.7,135.0,203.8 ; \mathrm{MS}$ (IE) $\mathrm{m} / \mathrm{z} 196$ (M $+, 53), 154(95), 125(100), 89(87)$.

(2S, 3R)- $N, N$-Diethyl-3-thiophenyl-2-hydroxy-propionamide (8a).

To a solution of epoxyamide $\mathbf{3 b}(50 \mathrm{mg}, 0.22 \mathrm{mmol})$ and thiophenol $(58 \mu \mathrm{L}, 0.55 \mathrm{mmoL})$ in THF $(1.8$ $\mathrm{mL}$ ) cooled at $-78{ }^{\circ} \mathrm{C}$ was added ytterbium triflate $(226 \mathrm{mg}, 0.34 \mathrm{mmol})$. This solution was stirred overnight, during which the temperature was allowed to warm to RT. The reaction mixture was then

\footnotetext{
${ }^{4}$ Meth-Cohn, O.; Chen, Y. Tetrahedron Lett. 1999, 40, 6069.
} 
diluted with diethyl ether and water, and the organic phase separated. The aqueous phase was extracted twice with diethyl ether and the combined organic phases were dried over $\mathrm{MgSO}_{4}$ and concentrated. The crude product was purified by column chromatography with a mixture of light petroleum ether and ethyl acetate (9/1 to $1.5 / 1)$ as the eluant to give a white solid in $80 \%$ yield and $97 \%$ ee. mp $92-93^{\circ} \mathrm{C}$; $[\alpha]_{\mathrm{D}}-197$ (c 1.1, chloroform); IR (film) 3255, 1620, 1495, 1475, 1435, 1260, 1060, 750, 725, $695 \mathrm{~cm}^{-1}$; $\delta_{\mathrm{H}}\left(400 \mathrm{MHz}, \mathrm{CDCl}_{3}\right) 1.05(\mathrm{t}, J 7.1,3 \mathrm{H}), 1.12(\mathrm{t}, J 7.1,3 \mathrm{H}), 3.05(\mathrm{~m}, 3 \mathrm{H}), 3.22$ (sextet, $J$ 7.1, $\left.1 \mathrm{H}\right), 3.56$ (sextet, $J 7.1,1 \mathrm{H}), 4.33(\mathrm{~d}, J 3.9,1 \mathrm{H}), 4.67(\mathrm{~d}, J 3.9,1 \mathrm{H}), 7.20-7.38(\mathrm{~m}, 8 \mathrm{H}), 7.40(\mathrm{dd}, J 7.3,1.9,2 \mathrm{H})$; $\delta_{\mathrm{C}}\left(100 \mathrm{MHz}, \mathrm{CDCl}_{3}\right) 12.7,14.2,40.5,41.2,57.9,69.9,127.5,127.9,128.2,129.0,132.5,134.9,136.9$, 170.4; MS (CI) m/z 330 (M+1 , 30), 312 (32), 220 (33), 204 (100), 131 (40), 204 (100), 111(83), 100 (79), 91 (39), 74 (45); anal. calcd for $\mathrm{C}_{19} \mathrm{H}_{23} \mathrm{NO}_{2} \mathrm{~S}$ : C, 69.27; H, 7.04; N, 4.25. Found: C, 69.72; H, $6.94 ; \mathrm{N}, 4.50$.

$(2 R, 3 R)$ - $N, N$-Diethyl-3-azido-2-hydroxy-propionamide $(8 \mathrm{~b})$.

To a solution of epoxyamide $\mathbf{3 d}(17 \mathrm{mg}, 0.073 \mathrm{mmol})$ and azidotrimethylsilane $(24 \mu \mathrm{L}, 0.18 \mathrm{mmoL})$ in THF $(1.8 \mathrm{~mL})$ cooled at $-78{ }^{\circ} \mathrm{C}$ was added ytterbium triflate $(67 \mathrm{mg}, 0.11 \mathrm{mmol})$. This solution was stirred overnight, during which the temperature was allowed to warm to RT. The reaction mixture was then diluted with diethyl ether and water, and the organic phase separated. The aqueous phase was extracted twice with diethyl ether and the combined organic phases were dried over $\mathrm{MgSO}_{4}$ and concentrated. The crude product was purified by column chromatography with a mixture of light petroleum ether and ethyl acetate (9/1 to 1.5/1) as the eluant to give a white solid in $80 \%$ yield and $97 \%$ ee. $\mathrm{mp} 89-90^{\circ} \mathrm{C} ;[\alpha]_{\mathrm{D}}-114.5$ (c 1, chloroform); IR (film) 3130, 2095, 1620, 1495, 1255, 1085, 825, $725,675 \mathrm{~cm}^{-1} ; \delta_{\mathrm{H}}\left(400 \mathrm{MHz}, \mathrm{CDCl}_{3}\right) 1.14(\mathrm{t}, J 7.2,3 \mathrm{H}), 1.22(\mathrm{t}, J 6.9,3 \mathrm{H}), 2.36(\mathrm{~s}, 3 \mathrm{H}), 3.20(\mathrm{~m}, 2 \mathrm{H})$, $3.40-3.51(\mathrm{~m}, 2 \mathrm{H}), 3.66(\mathrm{~m}, 1 \mathrm{H}), 4.47(\mathrm{~d}, J 6.7,1 \mathrm{H}), 4.58(\mathrm{~d}, J 6.7,1 \mathrm{H}), 7.20(\mathrm{~d}, J 8.2,2 \mathrm{H}), 7.24(\mathrm{~d}, J$ $8.2,2 \mathrm{H}) ; \delta_{\mathrm{H}}\left(400 \mathrm{MHz}, \mathrm{CDCl}_{3}\right) \delta_{\mathrm{C}}\left(100 \mathrm{MHz}, \mathrm{CDCl}_{3}\right) 12.8,14.3,21.3,40.8,41.6,68.5,70.3,127.9$, $129.5,132.7,138.8,170.7$.

trans- $N, N$-Diethyl-3-[2-(8-phenyloctyl)phenyl]-2,3-epoxypropionamide (11).

This compound was obtained from 2-(8-phenyloctyl)benzaldehyde $\mathbf{1 0}$ according to the general procedure, at $-30^{\circ} \mathrm{C}$ and for 24 hours. After purification by flash chromatography on silica gel with a mixture of petroleum ether and ethyl acetate (10/1 to 3/1) as the eluant, a colorless oil was obtained in $77 \%$ yield and $90 \%$ ee. $[\alpha]_{\mathrm{D}}-72.1$ ( $c$ 1.11, chloroform); $\delta_{\mathrm{H}}\left(400 \mathrm{MHz}, \mathrm{CDCl}_{3}\right) 1.15(\mathrm{t}, J$ 6.9, 3H), 1.20 $(\mathrm{t}, J 7.2,3 \mathrm{H}), 1.29(\mathrm{~m}, 8 \mathrm{H}), 1.4-1.65(\mathrm{~m}, 4 \mathrm{H}), 2.50(\mathrm{t}, J 7.7,2 \mathrm{H}), 2.64(\mathrm{~m}, 2 \mathrm{H}), 3.35(\mathrm{~m}, 4 \mathrm{H}), 3.40(\mathrm{~d}, J$ 2, $1 \mathrm{H}), 4.2(\mathrm{~d}, J 2,1 \mathrm{H}), 7.05-7.35(\mathrm{~m}, 9 \mathrm{H}) ; \delta_{\mathrm{C}}\left(100 \mathrm{MHz}, \mathrm{CDCl}_{3}\right)$ 13,0, 15,0, 29.3, 29.4, 29., 29.6, 31.6, $31.7,32.7,36,0,55,8,56.7,124.3,125.6,126.2,128.2,128.4,129.5,133.9,141.4,142.9,165.9$; MS (EI) m/z 407 (M+11), 389 (35), 160 (34), 131 (45), 115 (68), 105 (50), 100 (100) 91 (92), 72 (78); Anal. calcd for $\mathrm{C}_{27} \mathrm{H}_{37} \mathrm{NO}_{2}$ : C, 79.56; H, 9.15; N, 3.43. Found: C, 79.54; H, 9.21; N, 3.32; HRMS (EI) calcd for $\mathrm{C}_{27} \mathrm{H}_{38} \mathrm{NO}_{2}$ 408.2902, found 408.2897; Chiracel OD, hexane-i-PrOH (95: 5) $0.7 \mathrm{~mL} / \mathrm{min}$, $18.1 \min (2 S, 3 R), 25.1 \min (2 R, 3 S)$.

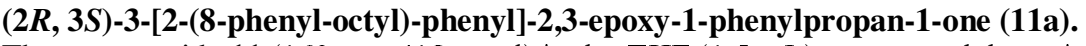

The epoxyamide 11 (160 mg, $412 \mu \mathrm{mol})$ in dry THF $(1.5 \mathrm{~mL})$ was treated dropwise with phenyllithium ( $2 \mathrm{M}$ solution in Cyclohexane/ether $70 / 30,618 \mu \mathrm{mol}$ ) at $-78{ }^{\circ} \mathrm{C}$ with stirring and after $30 \mathrm{~min}$. further reaction, water and ether was added. The organic layer was separated and the aqueous layer reextracted with ether. The combined organic layers were dried over $\mathrm{MgSO}_{4}$, concentrated, and the residue purified by flash chromatography with a mixture of light petroleum ether and ethyl acetate $(12 / 1$ to $8 / 1)$ as the eluant to give a colorless oil in $84 \%$ yield and $90 \%$ ee. $[\alpha]_{\mathrm{D}}-33.9(c 0.85$, chloroform); IR (film) 3025, 2925, 2855, 1690, 1595, 1580, 1495, $1450 \mathrm{~cm}^{-1} ; \delta_{\mathrm{H}}\left(400 \mathrm{MHz}, \mathrm{CDCl}_{3}\right)$ $1.19(\mathrm{~m}, 8 \mathrm{H}), 1.51(\mathrm{~m}, 4 \mathrm{H}), 2.55(\mathrm{t}, J 7.9,2 \mathrm{H}), 2.64(\mathrm{~m}, 2 \mathrm{H}), 4.21(\mathrm{~d}, J 1.6,1 \mathrm{H}), 4.25(\mathrm{~d}, J 1.6,1 \mathrm{H})$, $7.17(\mathrm{~m}, 4 \mathrm{H}), 7.27(\mathrm{~m}, 4 \mathrm{H}), 7.34(\mathrm{~m}, 1 \mathrm{H}), 7.46(\mathrm{~m}, 2 \mathrm{H}), 7.58(\mathrm{~m}, 1 \mathrm{H}), 8.02(\mathrm{~d}, J 8.1,1 \mathrm{H}) ; \delta_{\mathrm{C}}(100$ $\mathrm{MHz}, \mathrm{CDCl}_{3}$ ) 29.1, 29.2, 29.3, 29.4, 31.2, 31.3, 32.7, 35.9, 57.5, 60.4, 124.2, 125.5, 126.4, 128.2, 128.3, 128.4, 128.5, 128.8, 129.3, 133.3, 134.0, 135.5, 141.3, 142.8, 193.2; MS (EI) m/z $412\left(\mathrm{M}^{+}, 49\right)$, 131 (30), 117 (27), 105 (100); Chiracel OD, hexane-i-PrOH (99 : 1) $1.0 \mathrm{~mL} / \mathrm{min}, 26.6 \mathrm{~min}(2 S, 3 R)$, $36.3 \min (2 R, 3 S)$.

Phenyl (2R, 3S) 3-[2-(8-phenyl-octyl)-phenyl]-2,3-epoxy-propanoate (12).

A solution of epoxyketone (103mg, $0.25 \mathrm{mmol})$, and $m$-chloroperbenzoic acid $(128 \mathrm{mg}, 0.75 \mathrm{mmol})$ in $1.5 \mathrm{~mL}$ of dichloromethame were heated at reflux for $16 \mathrm{~h}$. The mixture was stirred with saturated aqueous sodium bisulfite for $2 \mathrm{~h}$ and then washed with a saturated sodium bicarbonate solution and brine. After evaporationg, the residue was purified by flash chromatography on silica gel with a mixture of light petroleum ether and ethyl acetate $(12 / 1$ to $8 / 1)$ as the eluant to give a colorless oil in 
$68 \%$ yield. $[\alpha]_{\mathrm{D}}-52.3$ (c 1.1, chloroform); IR (film) $2925,1770,14.95,1265,1165,745,690 \mathrm{~cm}^{-1} ; \delta_{\mathrm{H}}$ $\left(400 \mathrm{MHz}, \mathrm{CDCl}_{3}\right)$ 1.27-1.40 (m, 8H), 1.55-1.65 (m, 4H), $2.56(\mathrm{t}, J$ 7.8, 2H), $2.64(\mathrm{~m}, 2 \mathrm{H}), 2.75(\mathrm{~m}, J$ $7.3,2 \mathrm{H}), 3.62(\mathrm{~d}, J 1.9,1 \mathrm{H}), 4.41(\mathrm{~d}, J 1.9,1 \mathrm{H}), 7.14-7.30(\mathrm{~m}, 12 \mathrm{H}), 7.40(\mathrm{t}, J 8.0,2 \mathrm{H}) ; \delta_{\mathrm{C}}(100 \mathrm{MHz}$, $\left.\mathrm{CDCl}_{3}\right)$ 29.2, 29.4, 29.45, 29.58, 31.2, 31.4, 32.8, 35.9, 56.2, 56.5, 121.1, 124.4, 125.5, 126.4, 128.2, 128.3, 128.6, 129.3, 129.6, 141.4, 132.5, 141.4, 142.8, 150.2, 166.9; HRMS calcd for $\mathrm{C}_{29} \mathrm{H}_{32} \mathrm{O}_{3}{ }^{+}$ 428.2351, found 428.2346 Chiracel OD, hexane- $i-\mathrm{PrOH}(99: 1) 1.0 \mathrm{~mL} / \mathrm{min}, 24.0 \mathrm{~min}(2 R, 3 S)$, $26.9 \min (2 S, 3 R)$.

\section{Phenyl (2S, 3R), 3-\{[2-(methoxycarbonyl)ethyl]thio\}-2-hydroxy-3-[2-(8-phenyloctyl)-} phenyl]propanoate (13)

To a solution of epoxyester $12(72 \mathrm{mg}, 0.165 \mathrm{mmol})$ and methyl 3-mercaptopropionate (47 $\mu \mathrm{L}, 0.412$ $\mathrm{mmoL})$ in $\mathrm{CH}_{2} \mathrm{Cl}_{2}(1.5 \mathrm{~mL})$ cooled at $-78^{\circ} \mathrm{C}$ was added ytterbium triflate $(155 \mathrm{mg}, 0.24 \mathrm{mmol})$. This solution was stirred overnight, during which the temperature was allowed to warm to RT. The reaction mixture was then diluted with diethyl ether and water, and the organic phase separated. The aqueous phase was extracted twice with diethyl ether and the combined organic phases were dried over $\mathrm{MgSO}_{4}$ and concentrated. The crude product was purified by column chromatography with a mixture of light petroleum ether and ethyl acetate $(9 / 1$ to $1 / 1)$ as the eluant to give a colorless oil in $64 \%$ yield, $[\alpha]_{D}-$ 49.5 (c 1, chloroform); IR (film) 3470, 2925, 2855, 1740, 1590, 1490, 1360, 1190, 1160, 1095, 745, $700 \mathrm{~cm}^{-1} ; \delta_{\mathrm{H}}\left(400 \mathrm{MHz}, \mathrm{CDCl}_{3}\right) 1.27-1.35(\mathrm{~m}, 8 \mathrm{H}), 2.56-2.90(\mathrm{~m}, 8 \mathrm{H}), 3.35$ (broad, $\left.1 \mathrm{H}\right), 3.66(\mathrm{~s}, 3 \mathrm{H})$, $4.72(\mathrm{~d}, J 5.4,1 \mathrm{H}), 4.85(\mathrm{~d}, J 5.4,1 \mathrm{H}), 6.74(\mathrm{~d}, J 8.3,2 \mathrm{H}), 7.15-7.30(\mathrm{~m}, 8 \mathrm{H}), 7.72(\mathrm{~d}, J 7.8,1 \mathrm{H}) ; \delta_{\mathrm{C}}$ $\left(100 \mathrm{MHz}, \mathrm{CDCl}_{3}\right)$ 26.6, 29.3, 29.4 (2C), 29.7, 31.0, 31.4, 32.7, 34.3, 35.9, 51.8, 73.0, 121.1, 125.5, $126.2,126.4,128.0,128.2,128.3,128.7,129.4,129.6,134.8,140.8,142.8,150.1,170.6,172.1$ (1C missing), Chiracel OD, hexane- $i$-PrOH $(90: 10) 1.0 \mathrm{~mL} / \mathrm{min}, 19.4 \mathrm{~min}(2 S, 3 R), 23.1 \mathrm{~min}(2 R, 3 S)$.

$(2 S, 3 R), 3-\{[2-(c a r b o x y e t h y l]$ thio\}-2-hydroxy-3-[2-(8-phenyloctyl)-phenyl]-propanoic acid (14) A solution of $13(32 \mathrm{mg}, 0.06 \mathrm{mmol})$ in methanol $(0.5 \mathrm{~mL})$ was treated with an aqueous $2.5 \mathrm{~N}$ solution of sodium hydroxide $(0.105 \mathrm{~mL})$ at room temperature. The resulting mixture was stirred for 16 hours. Methanol was removed under reduced pressure. Water $(0.5 \mathrm{~mL})$ was added, $\mathrm{pH}$ was adjusted to 2 with a $0.1 \mathrm{~N}$ solution of hydrochloric acid, and the aqueous layer was extracted with ethyl acetate. The organic phase was dried over magnesium sulfate, filtrated and concentrated to give a colorless oil in 81 $\%$ yield $[\alpha]_{\mathrm{D}}-18.2$ ( $c 0.28$, chloroform); IR (film) 3025, 2925, 2855, 1710, 1495, 1455, 1245, 1095, $925,750,700 \mathrm{~cm}^{-1} ; \delta_{\mathrm{H}}\left(400 \mathrm{MHz}, \mathrm{CDCl}_{3}\right) 1.34(\mathrm{~m}, 8 \mathrm{H}), 1.60(\mathrm{~m}, 4 \mathrm{H}), 2.58-2.84(\mathrm{~m}, 8 \mathrm{H}), 4.58(\mathrm{~d}, J$ $4.7,1 \mathrm{H}), 4.64(\mathrm{~d}, J 4.7,1 \mathrm{H}), 7.18-7.30(\mathrm{~m}, 8 \mathrm{H}), 7.58(\mathrm{~d}, J 7.3,1 \mathrm{H}) ; \delta_{\mathrm{C}}\left(100 \mathrm{MHz}, \mathrm{CDCl}_{3}\right) 26.3,29.4$, $29.50,29.55,29.75,31.2,31.5,32.7,34.2,36.0,73.1,125.6,126.3,128.0,128.3,128.4,128.6,129.8$, $134.5,141.1,142.9,175.7,177.4$, (1C is missing). 


\section{Solvent effect}

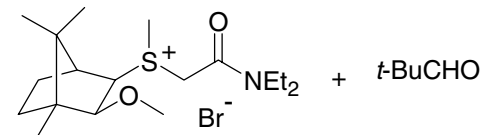

2

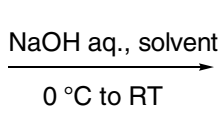

$\mathrm{O}^{\circ} \mathrm{C}$ to $\mathrm{RT}$

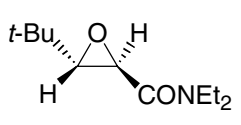

3)

Table 1. Asymmetric synthesis of 31: solvent effect ${ }^{a}$

\begin{tabular}{lllll}
\hline Entry & Solvent & Yield (\%) & Trans:Cis & Ee (\%) \\
\hline 1 & DCM & 90 & $>20: 1$ & 65 \\
2 & $t-\mathrm{BuOCH}_{3}$ & 93 & $>20: 1$ & 32 \\
3 & $\mathrm{PhCF}_{3}$ & 87 & $>20: 1$ & 55 \\
4 & $\mathrm{CH}_{3} \mathrm{CN}$ & 88 & $>20: 1$ & 54 \\
5 & $1,4-$ Dioxane & 85 & $>20: 1$ & 70 \\
6 & THF & 89 & $>20: 1$ & 52 \\
7 & EtOH & 85 & $>20: 1$ & 64 \\
8 & $n$-Hexane & 87 & $>20: 1$ & 76 \\
9 & Toluene & 84 & $>20: 1$ & 77
\end{tabular}

${ }^{a}$ Typical procedure: To a solution of pivaldehyde $(0.5 \mathrm{mmol})$ and chiral sulfonium salt $2(0.6 \mathrm{mmol})$ in the appropriate solvent $(2.0$ $\mathrm{mL})$ at $0{ }^{\circ} \mathrm{C}$ was added $10 \%$ aqueous $\mathrm{NaOH}(500 \mu \mathrm{L})$. The reaction mixture was stirred overnight, during which the temperature was allowed to warm to RT. After dilution with dichloromethane and water, the aqueous phase was extracted with dichloromethane several times. The combined organic phases were dried over $\mathrm{MgSO}_{4}$ and concentrated, and the crude product was purified by column chromatography on silica gel with a mixture of light petroleum ether and ethyl acetate (3/1) as the eluant to give to give the pure transepoxide $\mathbf{3 l}$ as a colorless oil. 


\section{Base effect}

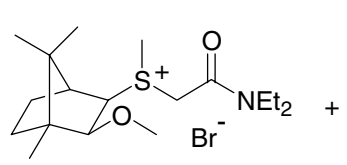

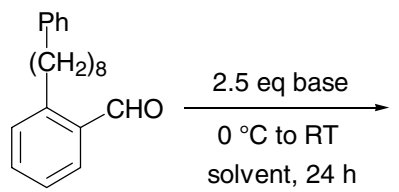

solvent, $24 \mathrm{~h}$

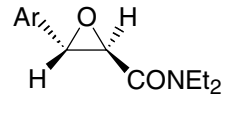

3i

Table 2. Asymmetric synthesis of $\mathbf{3 i}$ : base effect $^{a}$

\begin{tabular}{llllll}
\hline Entry & Base & Solvent & Trans:Cis & Yield (\%) & Ee (\%) \\
\hline 1 & $\mathrm{NaOH} 10 \%$ aq. & DCM & $>20: 1$ & 70 & 86 \\
2 & $\mathrm{Et}_{3} \mathrm{~N}$ & $\mathrm{DCM}$ & $>20: 1$ & 0 & - \\
3 & $\mathrm{DBU}$ & $\mathrm{DCM}$ & $>20: 1$ & 58 & 84 \\
4 & $t$ - $\mathrm{BuOK}$ & $\mathrm{DCM}$ & $>20: 1$ & 48 & 83 \\
5 & $\mathrm{KOH}$ & $\mathrm{DCM}$ & $>20: 1$ & 69 & 84 \\
6 & $\mathrm{EtP}_{2}$ & $\mathrm{DCM}$ & $>20: 1$ & 52 & 84 \\
7 & $\mathrm{DBU}$ & $\mathrm{EtOH}$ & $>20: 1$ & 42 & 86 \\
8 & $\mathrm{LiOH} . \mathrm{H}_{2} \mathrm{O}$ & $\mathrm{EtOH}$ & $>20: 1$ & 40 & 88 \\
9 & $\mathrm{KOEt}$ & $\mathrm{EtOH}$ & $>20: 1$ & 60 & 87 \\
10 & $\mathrm{KOH}$ & $\mathrm{EtOH}$ & $>20: 1$ & 63 & 87
\end{tabular}

${ }^{a}$ Typical procedure: To a solution of 2-(8-phenyloctyl)benzaldehyde $(0.35 \mathrm{mmol})$ and chiral sulfonium salt $2(0.42 \mathrm{mmol})$ in $\mathrm{DCM}$ or $\mathrm{EtOH}(1.5 \mathrm{~mL})$ at $0{ }^{\circ} \mathrm{C}$ was added the appropriate base $(2.5 \mathrm{eq})$ The reaction mixture was stirred 24 hours, during which the temperature was allowed to warm to RT. After dilution with dichloromethane and water, the aqueous phase was extracted with dichloromethane several times. The combined organic phases were dried over $\mathrm{MgSO}_{4}$ and concentrated, and the crude product was purified by column chromatography on silica gel with a mixture of petroleum ether and ethyl acetate (10/1 to 3/1) as the eluant to give the pure trans-3i as a colorless oil (yields nonoptimized). 


\section{Temperature effect}

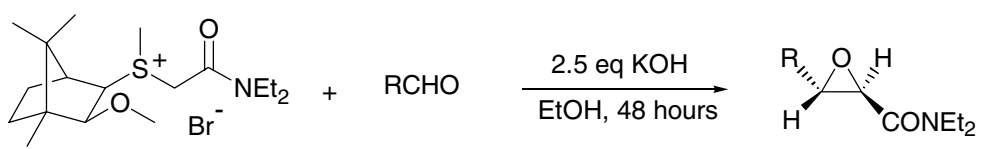

2

3

Table 3. Asymmetric synthesis of $(2 R, 3 S)-2,3$-epoxyamides: temperature effect

\begin{tabular}{lllllll}
\hline Entry & $\mathrm{R}$ & $\mathrm{T}\left({ }^{0} \mathrm{C}\right)$ & Trans:Cis & Product & Yield (\%) & Ee (\%) \\
\hline 1 & $o-\mathrm{Ph}-\left(\mathrm{CH}_{2}\right)_{8}-\mathrm{C}_{6} \mathrm{H}_{4}$ & 0 to RT & $>20: 1$ & $\mathbf{3 i}$ & $63^{\mathrm{a}}$ & 87 \\
2 & $o-\mathrm{Ph}-\left(\mathrm{CH}_{2}\right)_{8}-\mathrm{C}_{6} \mathrm{H}_{4}$ & -30 & $>20: 1$ & $\mathbf{3 i}$ & 77 & 90 \\
3 & $o-\mathrm{Ph}-\left(\mathrm{CH}_{2}\right)_{8}-\mathrm{C}_{6} \mathrm{H}_{4}$ & -50 & $>20: 1$ & $\mathbf{3 i}$ & $61^{\mathrm{a}}$ & 92 \\
4 & $t$ - $\mathrm{Bu}$ & 0 to RT & $>20: 1$ & $\mathbf{3 l}$ & 85 & 64 \\
5 & $t$ - $\mathrm{Bu}$ & -50 to RT & $>20: 1$ & $\mathbf{3 l}$ & $43^{\mathrm{a}}$ & 75 \\
6 & $t$ - $\mathrm{Bu}$ & -50 & $>20: 1$ & $\mathbf{3 l}$ & - & - \\
$7^{\mathrm{b}}$ & $t$ - $\mathrm{Bu}$ & -20 & $>20: 1$ & $\mathbf{3 l}$ & 84 & 93 \\
\hline
\end{tabular}

${ }^{a}$ Yield not optimized; ${ }^{b} 1$ eq. of salt 2 and 2 eq. pivaldehyde, $72 \mathrm{~h}$.

Reaction of our salt with $p$-ClPhCHO under identical Hou's salt conditions (ref. 9) is given below.
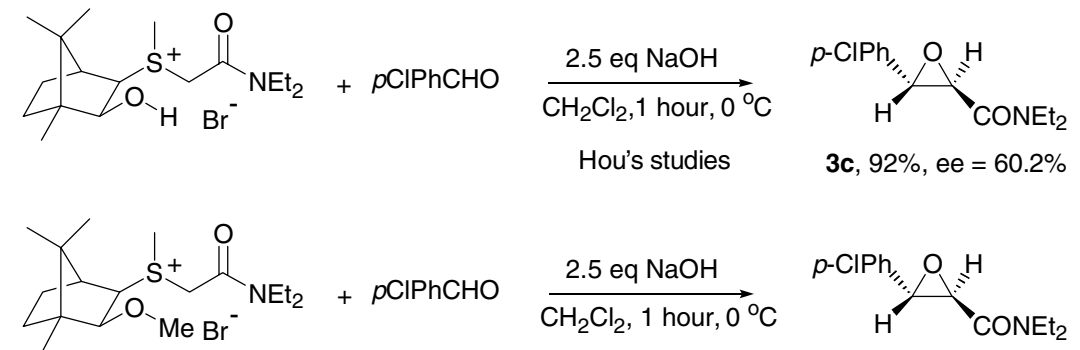

$\underset{\mathrm{CH}_{2} \mathrm{Cl}_{2}, 1 \text { hour, } 0^{\circ} \mathrm{C}}{\stackrel{2.5 \text { eq } \mathrm{NaOH}}{\longrightarrow}}$

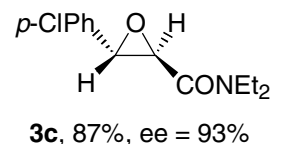

2

$3 c, 87 \%$, ee $=93 \%$

This shows that there is a significant difference in selectivity which must be associated with sulfide structure. There is a significant effect on enantioselectivity with change in temperature in the case of pivaldehyde but less so with aromatic aldehydes. 


\section{Salt ratio effect}

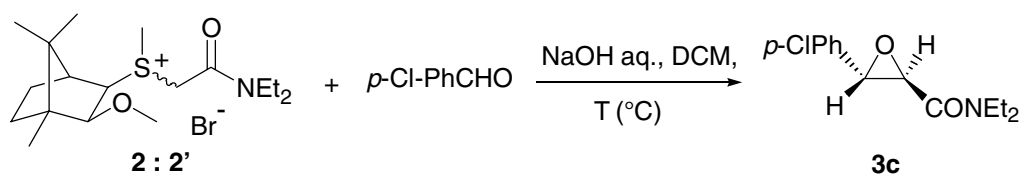

Table 4. Effect of the sulfonium salt 2 diastereoisomeric ratio ${ }^{a}$

\begin{tabular}{lllll}
\hline Entry & $\mathbf{2}: \mathbf{2}$ & $\mathrm{T}\left({ }^{\circ} \mathrm{C}\right)$ & Trans:Cis & $\mathrm{Ee}(\%)$ \\
\hline 1 & $1.1: 1$ & 0 & $>20: 1$ & 76 \\
2 & $4.2: 1$ & 0 & $>20: 1$ & 80 \\
3 & $4.5: 1$ & 0 & $>20: 1$ & 81 \\
4 & $15: 1$ & 0 & $>20: 1$ & 93 \\
5 & $100: 0$ & 0 & $>20: 1$ & 93 \\
6 & $1.2: 1$ & 40 & $>20: 1$ & 40 \\
7 & $4.4: 1$ & 40 & $>20: 1$ & 78 \\
8 & $100: 0$ & 40 & $>20: 1$ & 84 \\
\hline
\end{tabular}

${ }^{a}$ Typical procedure: To a solution of p-chlorobenzaldehyde $(70 \mathrm{mg}, 0.5$ $\mathrm{mmol})$ and chiral sulfonium salt $2(245 \mathrm{mg}, 0.6 \mathrm{mmol})$ in dichloromethane $(2.0 \mathrm{~mL})$ at 0 or $40{ }^{\circ} \mathrm{C}$ was added $10 \%$ aqueous $\mathrm{NaOH}(500 \mu \mathrm{L})$ The reaction mixture was stirred for 2 hours. After dilution with dichloromethane and water, the aqueous phase was extracted with dichloromethane several times. The combined organic phases were dried over $\mathrm{MgSO}_{4}$ and concentrated, and the crude product was purified by column chromatography on silica gel with a mixture of light petroleum ether and ethyl acetate (3/1) as the eluant to give to give the pure transepoxide 3c. 


\section{Retention times}

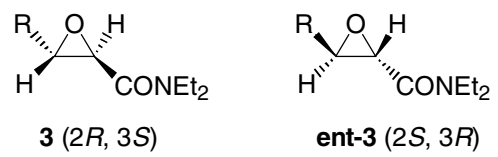

Table 5. Epoxyamides: retention times

\begin{tabular}{lllcccc}
\hline Entry & $\mathrm{R}$ & Column & $\begin{array}{c}\text { Conditions } \\
\text { Hexane }: i \text {-PrOH }\end{array}$ & $\begin{array}{c}\text { Flow } \\
(\mathrm{mL} / \mathrm{min})\end{array}$ & $\begin{array}{c}\text { Retention time (min) } \\
\text { ent-3 }\end{array}$ & $\mathbf{3}$ \\
\hline 1 & $p-\mathrm{MeOC}_{6} \mathrm{H}_{4}$ & OD & $95: 5$ & 0.7 & 34.1 & 38.4 \\
2 & $\mathrm{Ph}$ & ODH & $91: 10$ & 0.7 & 13.2 & 14.1 \\
3 & $p-\mathrm{ClC}_{6} \mathrm{H}_{4}$ & OJ & $80: 20$ & 0.7 & 14.0 & 17.5 \\
4 & $p-\mathrm{MeC}_{6} \mathrm{H}_{4}$ & OD & $95: 5$ & 0.7 & 8.6 & 10.1 \\
5 & $p-\mathrm{FC}_{6} \mathrm{H}_{4}$ & OJ & $85: 15$ & 0.7 & 10.8 & 11.8 \\
6 & $p-\mathrm{CF}_{3} \mathrm{C}_{6} \mathrm{H}_{4}$ & OJ & $85: 15$ & 0.7 & 8.0 & 9.2 \\
7 & $p-\mathrm{NO}_{2} \mathrm{C}_{6} \mathrm{H}_{4}$ & OJ & $80: 20$ & 0.6 & 26.5 & 27.6 \\
8 & $3-\mathrm{Pyridyl}_{9}$ & OD & $80: 20$ & 0.7 & 13.8 & 17.5 \\
9 & Dodecyl & OD & $99: 1$ & 0.7 & 31.3 & 33.1 \\
10 & $i$-Pr & OJ & $99: 1$ & 0.7 & 21.7 & 23.6 \\
11 & $t$ - $\mathrm{Butyl}$ & OJ & $99: 1$ & 0.7 & 17.2 & 18.6 \\
12 & $o-\mathrm{Ph}-\left(\mathrm{CH}_{2}\right)_{8}$ & OD & $95: 5$ & 0.7 & 18.1 & 25.1 \\
\hline
\end{tabular}


${ }^{1} \mathrm{H}$ NMR of $\mathbf{3 j}$

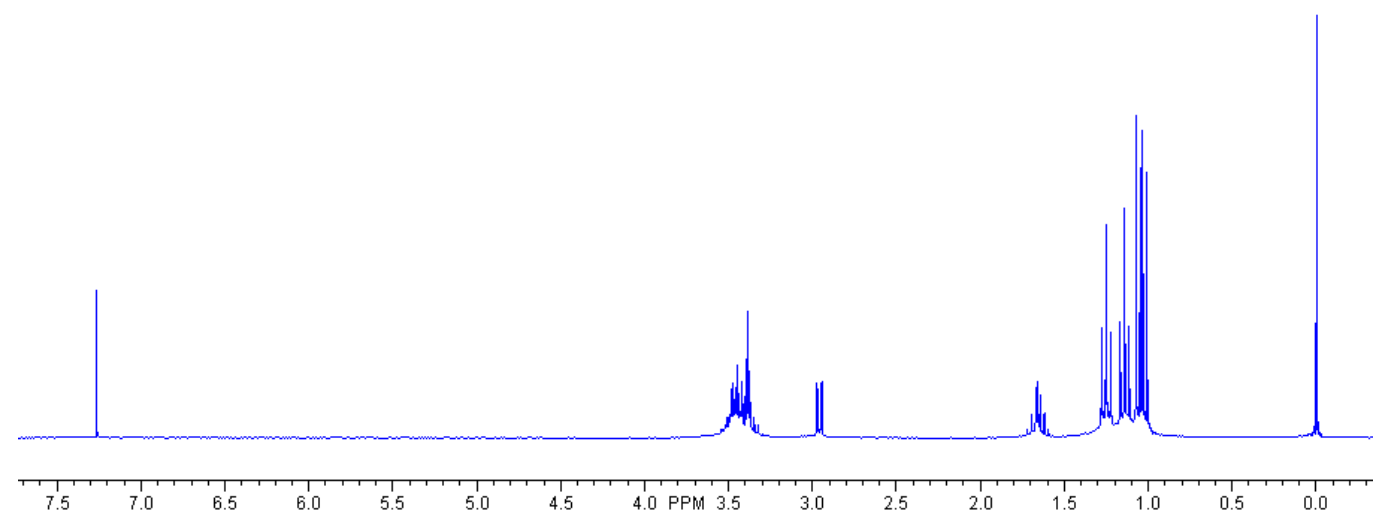

${ }^{1} \mathrm{H}$ NMR of $\mathbf{7 b}$
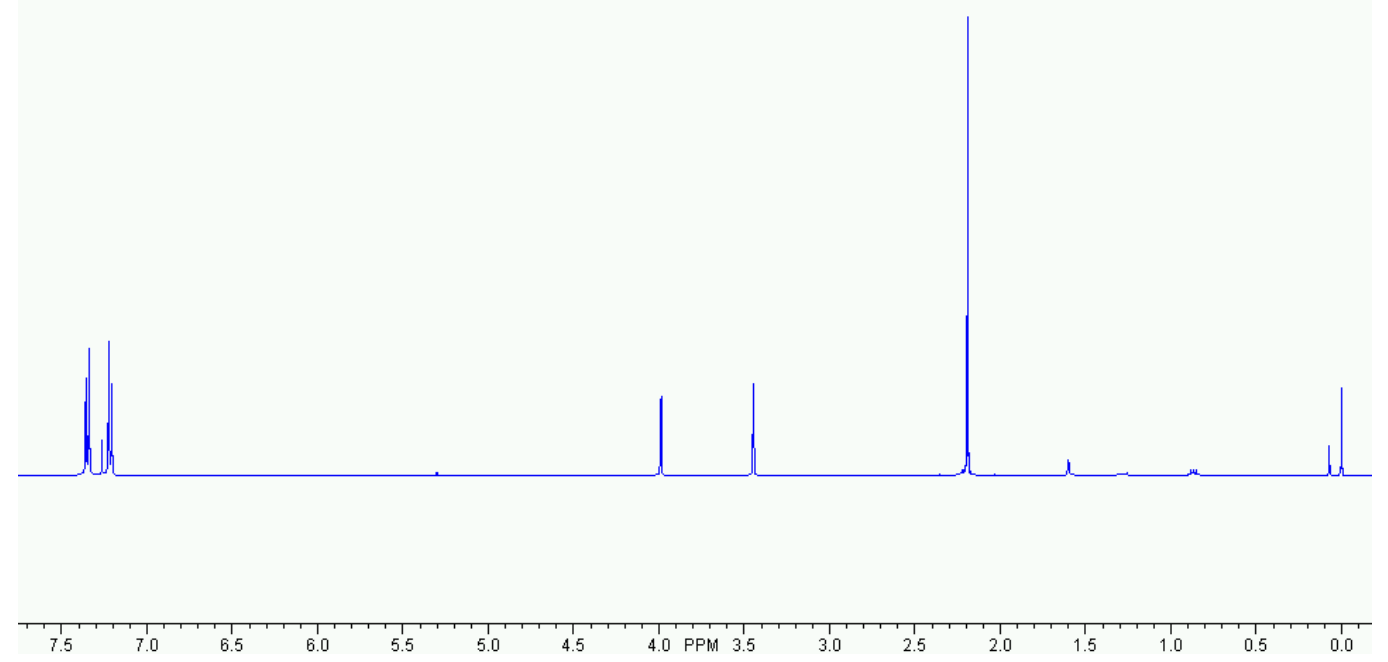

${ }^{1} \mathrm{H}$ NMR of $\mathbf{8 b}$

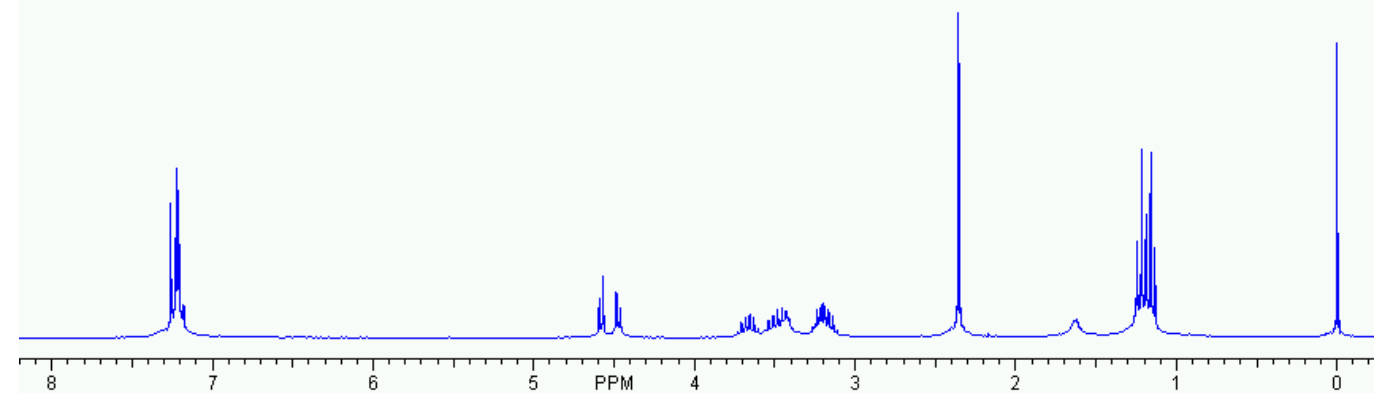


${ }^{1} \mathrm{H}$ NMR of 12a
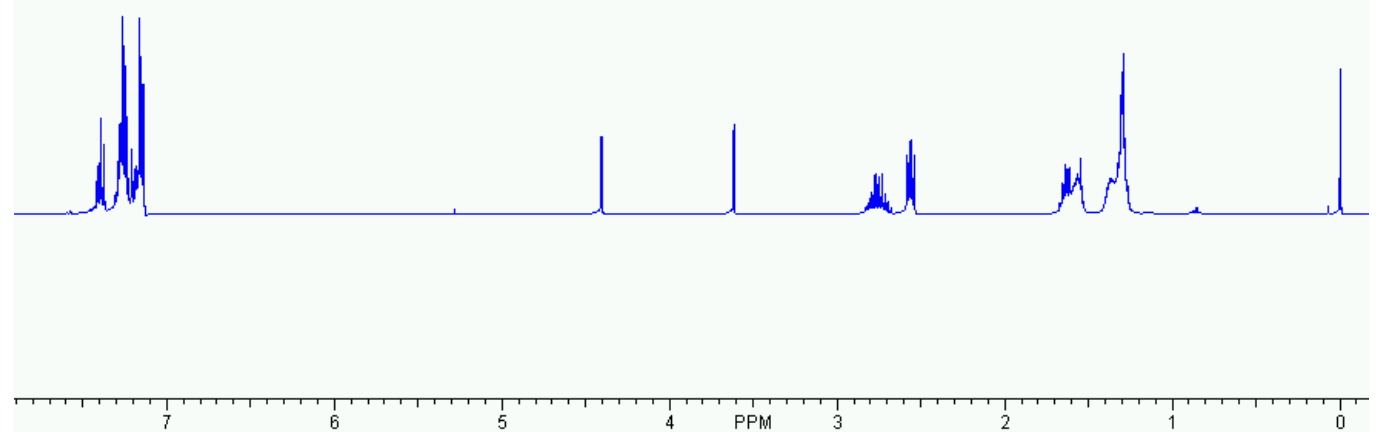

${ }^{1} \mathrm{H}$ NMR of $\mathbf{1 3}$
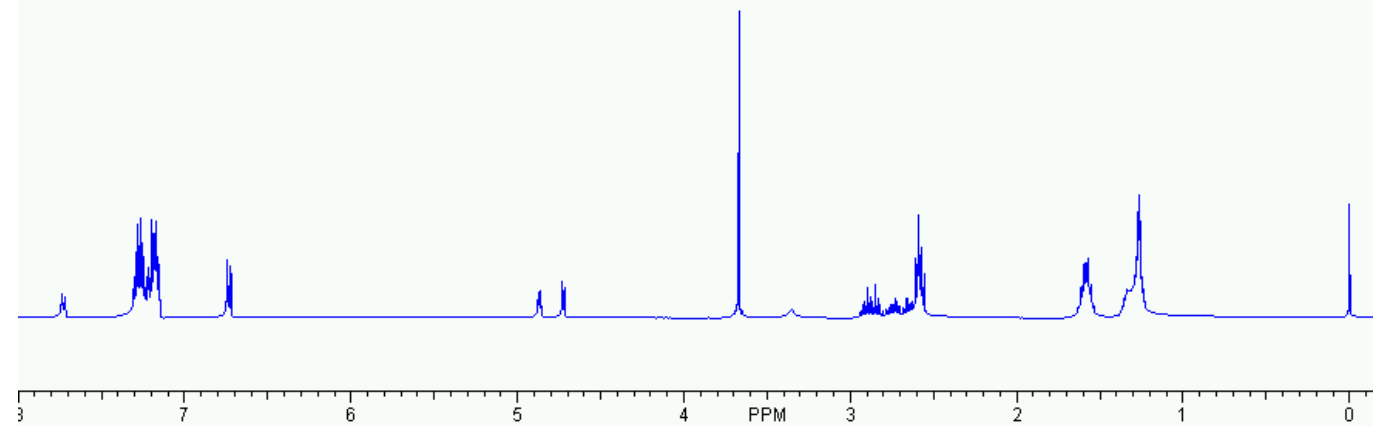

${ }^{1}$ H NMR of 14
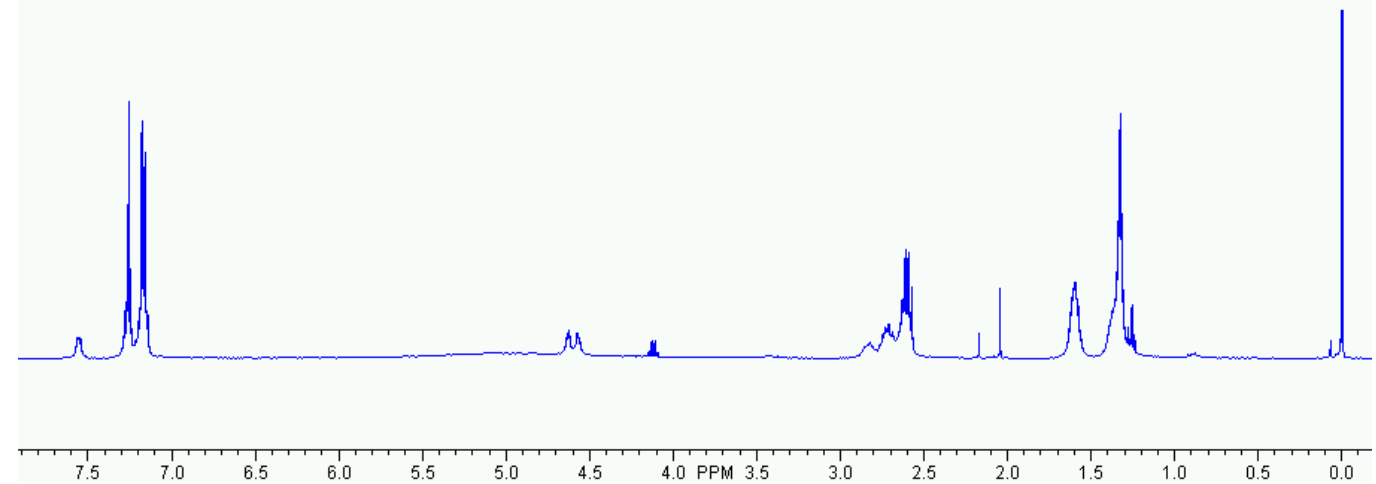